\title{
Comparative Study on Importance of Institutions to Address the Intergenerational Occupational Mobility in Farming Sector in Tribal and Coastal Districts of Odisha, India
}

\author{
Anshuman Jena* and Aditya Prasad Kanungo
}

Department of Extension Education, College of Agriculture, OUAT, Bhubaneswar, India

*Corresponding author

\section{A B S T R A C T}

\section{Keywords}

Coastal, extension functionaries, occupation, institution, tribal, youth

\section{Article Info}

Accepted:

15 December 2019

Available Online:

20 January 2020
In order to feed the country's population in general and our state in particular, farming is a must and we shouldn't leave any stone unturned to minimise the migrations from rural to urban and make agriculture so attractive for urbanites to move in the reverse direction. The present study was carried out from July 2016 to March 2017 with a perceptual and comparative analysis among the extension functionaries of coastal district (Jagatsinghpur) and tribal district (Mayurbhanj) of Odisha state with the total sample of 32 extension functionaries out of which 16 each from tribal and coastal institutions selected through random sampling in an intention to find out the importance of institutions to address intergenerational occupational mobility in farming sector. An attempt was made to find out the responses of the extension agents from the line departments, KVKs, NGOs and other organisations working for the development of farming sector at grass root level as well as assisting in policy making on the intergenerational occupational mobility in farming sector and major reasons behind this occupational mobility across the generation. The study found major requirements of timely input availability (mean=4.44) followed by participatory planning $($ mean=4.38) in tribal and insurance on all major crops $($ mean=4.50) followed by participatory planning (mean=3.94)might help to provide better income from farming and could orient the next generation to be involved in farming. The result showed higher family pressure in coastal than the tribal district which made the new generation less aspirants for farming as their occupation.

\section{Introduction}

Agriculture will continue to play an important role in the economic development and poverty alleviation in India even in the era of economic liberalization and globalization. Generation of gainful employment and income for the rural poor, strengthening of household food and nutritional security and sustainable use of natural resources shall continue to be the main objectives of agricultural development in the country. However, there would be a paradigm shift in the development strategy. Knowledge will be the key catalyst of growth, besides the traditional sources of growth like land and other resources. These 
developments will require significant changes in a majority of the existing institutions to keep them relevant in the present context. The institutions for management of land, water and other common resources should involve their users and other stakeholders for efficient, sustainable and equitable use of these resources. The institutions dealing with agricultural marketing and credit should reach and protect the interests of small farmers, besides increasing economic efficiency. The most significant change will, however, be witnessed in the institutions dealing with creation, protection, exchange and application of new knowledge and technologies. Hegde and Venkattakumar (2015) explained that ICAR and SAU has a major role to play in collaboration with KVK, capacity building organizations like MANAGE, NAARM, NIFTEM and private and non-governmental institutions to design customized programmes and build platforms for training, knowledge sharing and policy dialogues to check the occupational mobility in farming sector to non-farm sector. Proctor and Lucchesi (2012) acknowledged that issues of youth and youth employment are raising up the international policy agenda; there remains a low level of policy and investment intervention that focuses explicitly on rural youth and on youth employment opportunities in the agriculture and agribusiness sectors. Baba et al., (2010) in their work focused on agricultural growth and rural development in Himachal Pradesh found a positive and highly significant effect of public sector investment in agriculture on private investments in agriculture for the period 1969-2002.

\section{Materials and Methods}

The present study was carried out from July 2016 to March 2017 with a perceptual and comparative analysis among the extension functionaries of coastal district (Jagatsinghpur) and tribal district
(Mayurbhanj) of Odisha state with the total sample of 32 extension functionaries out of which 16 each from tribal and coastal institutions like KVK, line departments, credit institutions and NGOs working in farming sector selected through random sampling in an intention to find out the importance of institutions to address intergenerational occupational mobility in farming sector. Various statistical tools like percentage, mean, standard deviation, $\mathrm{cv}$ and have been used in this study to make inferences from the collected data on impact of intergenerational occupational mobility in farming sector in coastal and tribal areas of Odisha.

\section{Results and Discussion}

\section{Attitude of extension agents on reasons of IOM in farming sector}

The table-1containing informations from the extension agents revealed that financial conditions (4.5) followed by lack of profit in agriculture (4.25), improper market linkage (4.25), lack of skills (4.25) etc. showed higher mean value in tribal area whereas urban outlook (4.75) followed by higher education (4.38) showed higher mean value in coastal area in depicting the reasons for intergenerational occupational mobility in farming sector. It was found that lack of skills $(10.52 \%)$, improper market linkage $(10.52 \%)$, lack of profit in agriculture (10.52\%), financial conditions (11.48\%) and cultural factors $(12.98 \%)$ showed lower value of coefficient of variation in describing more precisely the reasons of intergenerational occupational mobility in farming sector in tribal areas by showing less variation to the mean. In coastal areas, the extension agents expressed that urban outlook $(9.42 \%)$, higher Education (11.43\%), and social status (16.26\%), family Pressure (17.66\%) were the major reasons for intergenerational occupational mobility in the farming sector. 
Higher education and urban outlook in costal district affected more as compared to tribal area which motivated them to choose jobs in different government and private sectors as they had the perception that farming as the old age occupation. The result showed higher family pressure in coastal than the tribal district which made the new generation less aspirants for farming as their occupation. Besides that, the tribal area respondents faced more problems as compared to coastal area such as less education and awareness, lack of availability of quality inputs timely etc. which made them vulnerable in the farming sector.

Institutional strategies need to be taken to address IOM

The table: 2 derived that for the respondents of tribal districts, there was major requirements of timely input availability (mean=4.44) followed by participatory planning (mean=4.38) and market intelligence and access (mean=4.38) which might help to provide better income from farming and could orient the next generation to be involved in farming. In coastal district, insurance on all major crops(mean=4.50) followed by participatory planning $($ mean $=3.94)$ resulted as the necessary strategies to be considered which might check intergenerational occupational mobility in farming sector by considerably minimising risk in farming. The respondents of tribal district witnessed higher variation in need of insurance for all major crops and availability of modern technologies whereas the coastal area respondents witnessed higher variation in need of market intelligences with better access to markets and requirements of filed visits etc could motivate them for their involvement in farming occupation by checking the intergenerational occupational mobility.

Table.1 Attitude of extension agents on reasons of IOM in farming sector

(Minimum=1, Maximum=5)

\begin{tabular}{|c|c|c|c|c|c|c|}
\hline \multirow[t]{2}{*}{ Reasons } & \multicolumn{2}{|c|}{ Mean } & \multicolumn{2}{|c|}{ SD } & \multicolumn{2}{|c|}{$\mathbf{C V}$} \\
\hline & Tribal & Coastal & Tribal & Coastal & Tribal & Coastal \\
\hline Higher Education & 2.31 & 4.38 & 0.48 & 0.50 & 20.70 & 11.43 \\
\hline $\begin{array}{c}\text { Lack of Awareness } \\
\text { of modern } \\
\text { technologies }\end{array}$ & 4.00 & 2.50 & 0.73 & 0.52 & 18.26 & 20.66 \\
\hline $\begin{array}{l}\text { Financial } \\
\text { conditions }\end{array}$ & 4.50 & 3.13 & 0.52 & 0.62 & 11.48 & 19.81 \\
\hline Social status & 3.56 & 2.75 & 0.51 & 0.45 & 14.38 & 16.26 \\
\hline Cultural factors & 3.69 & 1.75 & 0.48 & 0.86 & 12.98 & 48.93 \\
\hline $\begin{array}{l}\text { Lack of profit in } \\
\text { agriculture }\end{array}$ & 4.25 & 3.25 & 0.45 & 0.68 & 10.52 & 21.02 \\
\hline Urban outlook & 3.31 & 4.75 & 0.48 & 0.45 & 14.45 & 9.42 \\
\hline Family Pressure & 2.75 & 3.56 & 0.58 & 0.63 & 20.99 & 17.66 \\
\hline $\begin{array}{l}\text { Untimely Input } \\
\text { availability }\end{array}$ & 3.63 & 2.94 & 0.62 & 0.57 & 17.08 & 19.53 \\
\hline $\begin{array}{c}\text { Improper market } \\
\text { linkage }\end{array}$ & 4.25 & 2.50 & 0.45 & 0.63 & 10.52 & 25.30 \\
\hline Lack of skills & 4.25 & 2.13 & 0.45 & 0.62 & 10.52 & 29.14 \\
\hline
\end{tabular}


Table.2 Institutional strategies need to be taken to address IOM

(Minimum=1, Maximum=5)

\begin{tabular}{|c|c|c|c|c|c|c|}
\hline \multirow{2}{*}{ Strategies } & \multicolumn{2}{|c|}{ Mean } & \multicolumn{2}{|c|}{ SD } & \multicolumn{2}{|c|}{ CV } \\
\hline & Tribal & Coastal & Tribal & Coastal & Tribal & Coastal \\
\hline $\begin{array}{c}\text { Training/ } \\
\text { Capacity building }\end{array}$ & 4.31 & 3.56 & 0.48 & 0.73 & 11.10 & 20.42 \\
\hline $\begin{array}{l}\text { Group formation/ } \\
\text { Farmers' club }\end{array}$ & 4.00 & 3.31 & 0.73 & 0.48 & 18.26 & 14.45 \\
\hline $\begin{array}{l}\text { Participatory } \\
\text { Planning }\end{array}$ & 4.38 & 3.94 & 0.50 & 0.68 & 11.43 & 17.27 \\
\hline $\begin{array}{l}\text { Institutional } \\
\text { linkage }\end{array}$ & 4.31 & 3.13 & 0.48 & 0.62 & 11.10 & 19.81 \\
\hline $\begin{array}{l}\text { Insurance on all } \\
\text { major crops }\end{array}$ & 3.94 & 4.50 & 0.68 & 0.52 & 17.27 & 11.48 \\
\hline $\begin{array}{c}\text { Market } \\
\text { intelligence \& } \\
\text { access }\end{array}$ & 4.38 & 2.81 & 0.50 & 0.83 & 11.43 & 29.66 \\
\hline $\begin{array}{l}\text { Modern } \\
\text { implements } \\
\text { availability }\end{array}$ & 3.88 & 3.13 & 0.62 & 0.50 & 15.98 & 16.00 \\
\hline Demonstrations & 4.06 & 3.38 & 0.44 & 0.62 & 10.89 & 18.34 \\
\hline Field visit & 3.50 & 3.00 & 0.52 & 0.73 & 14.75 & 24.34 \\
\hline $\begin{array}{l}\text { Timely input } \\
\text { availability }\end{array}$ & 4.44 & 3.63 & 0.51 & 0.62 & 11.55 & 17.08 \\
\hline Use of ICTs & 3.75 & 3.56 & 0.58 & 0.73 & 15.40 & 20.42 \\
\hline
\end{tabular}

Table.3 Institutional Problems in addressing IOM in farming sector

\begin{tabular}{|c|c|c|c|c|c|c|}
\hline \multirow{2}{*}{ Problems } & \multicolumn{4}{|c}{ Mean } & \multicolumn{4}{c|}{ SD } & \multicolumn{2}{c|}{ CV } \\
\cline { 2 - 7 } & Tribal & Coastal & Tribal & $\begin{array}{c}\text { Coasta } \\
1\end{array}$ & Tribal & Coastal \\
\hline $\begin{array}{c}\text { Lack of } \\
\text { infrastructure }\end{array}$ & 3.88 & 3.25 & 0.72 & 0.68 & 18.55 & 21.02 \\
\hline $\begin{array}{c}\text { Lack of fund } \\
\text { Lack of human } \\
\text { resource }\end{array}$ & 3.19 & 3.25 & 0.66 & 0.45 & $\mathbf{2 0 . 5 5}$ & 13.76 \\
\hline $\begin{array}{c}\text { Week farmer- } \\
\text { scientist linkage }\end{array}$ & $\mathbf{4 . 6 9}$ & $\mathbf{3 . 7 5}$ & 0.48 & 0.45 & 10.21 & 11.93 \\
\hline $\begin{array}{c}\text { Unavailability of } \\
\text { location specific } \\
\text { technologies }\end{array}$ & 3.50 & 2.75 & 0.52 & 0.45 & 14.75 & 16.26 \\
\hline
\end{tabular}

Institutional Problems in addressing IOM in farming sector
The table no. 3 interpreted various institutional problems in both tribal and coastal district which might be associated with 
the intergenerational occupational mobility in farming sector. Lack of human resource (4.69), weak farmer scientist linkage (4.38), lack of infrastructure (3.88) in tribal areas and lack of human resource (3.75), lack of infrastructure (3.25) and lack of fund (3.25) in coastal area showed higher mean value in depicting major institutional problems in accordance with intergenerational occupational mobility. In tribal area, lack of human resource $(10.21 \%)$, week farmerscientist linkage $(14.15 \%)$, unavailability of location specific technologies (14.75\%) where as in coastal area, lack of human resource $(11.93 \%)$ and lack of fund $(13.76 \%)$ precisely described major institutional problems in accordance with intergenerational occupational mobility in farming sector. Unavailability of location specific and need based technology and communication gap between scientists and farmers in tribal areas were found to be important constraints for the development of agriculture in those area and which forced the second generation to choose non-farm occupations for their better socioeconomic development.

The process of urbanisation and industrialisation pushed second generation of small and marginal land holders to opt for skilled and unskilled labour for getting better salary in comparison with the profit gained from their parental farming occupation which is also associated with high risk, market and weather uncertainty. Information from the extension agents revealed that financial conditions (4.5), lack of profit in agriculture (4.25), improper market linkage (4.25), lack of skills (4.25) etc. showed higher mean value in tribal area whereas urban outlook (4.75), higher education (4.38) showed higher mean value in coastal area in describing the reasons on intergenerational occupational mobility in farming sector. There was major requirements of timely input availability with mean score of 4.44 followed by participatory planning of mean score 4.38 and market intelligence and access (mean score $=4.38$ ) which might help to provide better income from farming sector and could orient and motivate the next generation for involvement in farming occupation in tribal district. In coastal district, insurance on all major crops having mean score 4.50 followed by participatory planning (mean score $=3.94$ ) resulted as the necessary strategies to be considered which might check intergenerational occupational mobility in farming sector by considerably minimising risk in farming. To check or minimise the intergenerational occupational mobility in farming sector, the state as well as the central government has initiated many agricultural development programmes and also needs to develop more effective programmes, projects, policies and schemes to attract the new generation through development and capacity building of farmers in general and rural youth in particular for bringing in sustainability farming sector and to provide them a better standard of living.

\section{References}

Azam M. 2015. Intergenerational Occupational Mobility among Men in India, Journal of Development Studies, 51(10): 1389-1408.

Baba SH, Saini AS, Sharma KD and Thakur DR. 2010. Impact of Investment on Agricultural Growth and Rural Development in Himachal Pradesh: Dynamics of Public and Private Investment, Indian Journal of Agricultural Economics, 65(1): 1-24.

Bello ARS, Allajabou HA, Baig MB. 2015. Attitudes of rural youth towards agriculture as an occupation: A case study from Sudan, International Journal of Development and Sustainability, 4(4): 415-424.

Hedge MR, Venkattakumar R. 2015. Technology Transfer and Skill 
Development towards Improved Proctor FJ and Lucchesi V. 2012. Small-scale Livelihood in Rural India, Indian farming and youth in an era of rapid Research Journal of Extension rural change, IIED/HIVOS, Education. 15 (4). 227-233. London/The Hague.

\section{How to cite this article:}

Anshuman Jena and Aditya Prasad Kanungo. 2020. Comparative Study on Importance of Institutions to Address the Intergenerational Occupational Mobility in Farming Sector in Tribal and Coastal Districts of Odisha. Int.J.Curr.Microbiol.App.Sci. 9(01): 31-36.

doi: https://doi.org/10.20546/ijcmas.2020.901.004 